leading articles in the Glasgow Herald which criticized the enrolment of foreign students in naval architecture and marine engineering. International cooperation, however, he considers, offers more of gain than of loss, in fact, "gain for all, with loss to none".

\section{The Zeppelin Centenary}

$\mathrm{Bx}$ the issue of commemorative stamps, the opening of a museum at Friedrichshafen, and in other ways, Germany has been paying homage to the memory of Count Ferdinand Zeppelin, of airship fame, the centenary of whose birth occurred on July 8. Born on the shores of Lake Constance, Count Zeppelin was educated at Stuttgart, and at twenty years of age became an infantry officer. His military studies led him to visit Italy, France and England, and in 1863 he served with the Union forces in the American Civil War, in the course of his service making a balloon ascent. Returning home, he took part in the war between Prussia and Austria and in the Franco-Prussian War and afterwards rose to high command. In 1891 he retired as a general. $\mathrm{He}$ had long conceived the idea of aerial navigation by airship, and free from official duties, and possessing considerable means, he devoted all his energies to the construction of a rigid airship. In 1900 he achieved his first success with $Z 1$, a craft $420 \mathrm{ft}$. long and $38 \frac{1}{2} \mathrm{ft}$. in diameter, the envelope of which contained seventeen gasbags with a total capacity of about $400,000 \mathrm{cub}$. $\mathrm{ft}$. of hydrogen. The two cars suspended beneath the ship had two 18 horse-power Daimler engines. On July 2, 1900, the airship was hauled out of its floating shed on Lake Constance and covered a distance of $3 \frac{1}{2}$ miles before being landed on the water and towed back to the shed. As a military officer, Zeppelin had visualized the use of airships for observations and for carrying dispatches, but their use as a means of transport was his chief aim, and one of his ambitions was to see Europe and America connected by an airship service. This, however, he did not live to see, for he died in Berlin on March 8, 1917, in the midst of the Great War.

\section{Auguste Forel and Alcoholism}

IN a paper on Auguste Forel and his campaign against alcoholism, read before the Society for the Study of Inebriety and Drug Addiction on July 12, Dr. J. D. Rolleston, after a short sketch of Forel's life, stated that though an active campaign against alcoholism had previously been carried out for many years in Great Britain and the United States, Forel was a pioneer in the scientific anti-alcoholic movement not only in Switzerland, his fatherland, but also on the continent of Europe. The lack of recognition of his work in Great Britain was attributed by Dr. Rolleston to two reasons. In the first place, Forel was strongly opposed to making the campaign against alcoholism inseparable from religion and Christianity in particular, as it is in this country and the United States. The second reason was the severe blow to Anglo-Saxon prudery and obscurantism caused by his classical work on the sexual question. On the other hand, the high appreciation of his work in foreign countries was shown by quotation of the opinions of eminent neurologists, psychiatrists and others in Germany, Hungary, Switzerland and the United States. Forel's contributions to the study of the alcohol problem were then considered under the headings of blastophthoria, alcoholism and the sexual question, exposure of popular errors concerning alcohol, such as the view that beer and wine do not cause alcoholism and the value of alcohol as a food, drug, and indispensable agent in sociability, alcohol and sport, and the treatment of alcoholism.

\section{Inland Water Survey}

DEFINITE quantitative results of the Inland Water Survey Committee's investigations are forthcoming in the Surface Water Year-Book of Great Britain 1935-36 (London: His Majesty's Stationery Office, $5 s$. net) which is a statistical report (issued by the Ministry of Health and the Scottish Office) relating to the inland water resources of Great Britain during the twelve months ended September 30, 1936. The publication provides detailed information about the surface water. resources of a dozen drainage basins, together with their rainfall. Results for underground water are being published separately in a different form. Twenty-seven rivers, at twenty-eight gauging stations, have been the subject of continuous measurement and the results are tabulated in regard to daily maximum and minimum water levels and daily mean discharge in cusecs. The Year-Book furnishes, moreover, in each case a brief description of the station and the drainage area, together with monthly evaluations of rainfall. The issue of this publication, which is to be continued annually, marks a further stage in the development of the Survey and it will be welcomed by all the various bodies who are interested in the use and application of water whether for agricultural purposes, or for land drainage, fisheries, industries, navigation, sewage disposal or water supplies and the like. Some useful conversion tables are included.

\section{The Norman Lockyer Observatory}

THE annual report of the Norman Lockyer Observatory, Sidmouth, shows that the activities of the Observatory are well maintained. The 12-in. McClean telescope has been used for taking spectra of $\zeta$ Aurigæ during its 1937 eclipse and also of Finsler's comet and of $A$-type stars. Its chief work has been in preparation for colour-temperature observations on early-type stars, and the preliminary experiments have shown that colour-temperature observations may be profitably taken up with this instrument. The 9-in. Kensington telescope has been used on a selected number of bright-line stars, with special attention to $\gamma$ Cassiopeiæ. Some photographs of star fields have been taken with the Zeiss triplet camera attached to the instrument. Three meteor cameras fixed outside the dome have been used for the photography of meteors, but unfortunately with. out success up to the present. Prof. Blumbach has used the Mond equatorial for photographs of galactic clusters, Finsler's Comet, and some test plates of the 